\title{
Serosurvey of Borrelia in dogs, horses, and humans exposed to ticks in a rural settlement of southern Brazil
}

\author{
Soroprevalência e fatores associados a Borrelia em cães, equinos e humanos expostos a carrapatos \\ em um assentamento rural do sul do Brasil

\begin{abstract}
Denise Amaral Gomes Nascimento ${ }^{1}$; Rafael Felipe da Costa Vieira²; Thállitha Samih Wischral Jayme Vieira ${ }^{1}$; Roberta dos Santos Toledo ${ }^{1}$; Katia Tamekuni ${ }^{1}$; Nelson Jessé Rodrigues dos Santos ${ }^{1}$; Daniela Dibb Gonçalves ${ }^{3}$; Maria Luísa Vieira'; Alexander Welker Biondo²; Odilon Vidotto ${ }^{1 *}$
\end{abstract}

\begin{abstract}
${ }^{1}$ Departamento de Medicina Veterinária Preventiva, Universidade Estadual de Londrina - UEL, Londrina, PR, Brasil
${ }^{2}$ Departamento de Medicina Veterinária, Universidade Federal do Paraná - UFPR, Curitiba, PR, Brasil

${ }^{3}$ Departamento de Medicina Veterinária e Saúde Pública, Universidade Paranaense - UNIPAR, Umuarama, PR, Brasil

${ }^{4}$ Grupo de Leptospirose e Doença de Lyme, Unidade de Microbiologia Médica, Institute of Hygiene and Tropical Medicine - IHMT, Universidade Nova de Lisboa - UNL, Lisboa, Portugal
\end{abstract}

Received July 20, 2016

Accepted August 23, 2016

\begin{abstract}
The aims of the present study were to serosurvey dogs, horses, and humans highly exposed to tick bites for anti-Borrelia burgdorferi s.l. antibodies, identify tick species present, and determine risk factors associated with seropositivity in a rural settlement of Paraná State, southern Brazil. Eighty-seven residents were sampled, along with their 83 dogs and 18 horses, and individual questionnaires were administered. Immunofluorescence antibody test (IFAT) was performed on serum samples and positive samples were subjected to western blot (WB) analysis. Anti-B. burgdorferi antibodies were found in 4/87 (4.6\%) humans, 26/83 (31.3\%) dogs, and 7/18 (38.9\%) horses by IFAT, with 4/4 humans also positive by WB. Ticks identified were mostly from dogs and included 45/67 Rhipicephalus sanguineus, 21/67 Amblyomma ovale, and 1/67 A. cajennense sensu lato. All (34/34) horse ticks were identified as A. cajennense s.l.. No significant association was found when age, gender, or presence of ticks was correlated to seropositivity to Borrelia sp. In conclusion, although anti-Borrelia antibodies have been found in dogs, horses and their owners from the rural settlement, the lack of isolation, molecular characterization, absence of competent vectors and the low specificity of the commercial WB kit used herein may have impaired risk factor analysis.
\end{abstract}

Keywords: Immunofluorescence antibody test (IFAT), Lyme disease, serology, tick-borne disease, western blot.

\section{Resumo}

Os objetivos do presente estudo foram realizar um levantamento sorológico de cáes, cavalos e humanos altamente expostos a picadas de carrapatos para anticorpos anti-B. burgdorferi s.l., identificar as espécies de carrapatos presentes, e determinar os fatores de risco associados a soropositividade em um assentamento rural do Estado do Paraná, sul do Brasil. Oitenta e sete residentes foram amostrados junto com seus respectivos 83 cães e 118 cavalos e questionários individuais foram aplicados. O teste de imunofluorescência indireta (IFI) foi realizado nas amostras sorológicas e as positivas foram submetidas a análise por western blot (WB). Anticorpos anti-B. burgdorferi foram detectados em 4/87 (4,6\%) humanos, 26/83 (31,3\%) cães e 7/18 $(38,9 \%)$ cavalos pela IFI, com $4 / 4$ humanos também positivos pelo WB. Os carrapatos identificados foram em sua maioria de cães e incluíram 45/67 Rhipicephalus sanguineus, 21/67 Amblyomma ovale e 1/67 A. cajennense sensu lato. Todos (34/34) carrapatos dos cavalos foram identificados como A. cajennense s.l.. Não foram observadas diferenças estatísticas entre idade, sexo ou presença de carrapatos e soropositividade para Borrelia sp. Em conclusão, embora anticorpos anti-Borrelia tenham sido encontrados em cáes, equinos e seus proprietários do assentamento rural, a ausência de isolamento, caracterização molecular, ausência de vetores competentes e baixa especificidade do kit comercial de WB utilizado podem ter limitado a análise de fatores de risco.

Palavras-chave: Teste de imunofluorescência (IFI), doença de Lyme, sorologia, doenças transmitidas por carrapatos, western blot.

*Corresponding author: Odilon Vidotto. Departamento de Medicina

Veterinária Preventiva, Universidade Estadual de Londrina - UEL, Rodovia

Celso Garcia Cid, PR 445, Km 380, Campus Universitário, CEP 86051-990,

Londrina, PR, Brasil. e-mail: vidotto@uel.br 


\section{Introduction}

Lyme disease (LD) is a tick-borne disease caused by several bacteria in the Borrelia burgdorferi sensu lato (s.l.) complex (STANEK \& REITER, 2011). B. burgdorferi sensu stricto (s.s.), B. afzelii, and $B$. garinii have been identified as the major etiological agents of LD in Europe (STANEK et al., 2012). In South America, Borrelia spp. closely related to B. americana were found in Ixodes ticks from Uruguay (BARBIERI et al., 2013) and Argentina (NAVA et al., 2014). In southern Brazil, B. burgdorferi s.s. was reported to be found in Dermacentor nitens ticks removed from horses (GONÇALVES et al., 2014).

Because of differences in the clinical syndrome and vectors present in the region, LD in Brazil is also known as LD-like syndrome or Baggio-Yoshinari syndrome (BYS) (MANTOVANI et al., 2007). Although several human cases have been described throughout the country (YOSHINARI et al., 2003, 2007; CARRANZA-TAMAYO et al., 2012; ROSA et al., 2014), Borrelia spp. have not yet been isolated or characterized from such cases and Borrelia infection in humans remains to be confirmed in Brazil (YOSHINARI et al., 2010).

Domestic animals in Brazil have shown evidence of anti-B. burgdorferi s.l. antibodies, with the antibody seroprevalence in dogs ranging from less than $1 \%$ up to $51 \%$ (LABARTHE et al., 2003; ALVES et al., 2004; SPOLIDORIO et al., 2010; VIEIRA et al., $2013 \mathrm{a}, \mathrm{b}$ ) and, in horses, from $4.2 \%$ to $26.7 \%$ (GALO et al., 2009; SPOLIDORIO et al., 2010; VIEIRA et al., 2013a). Since studies in Brazil have focused either on suspected human cases or antibody prevalence in animals, the zoonotic etiology of Borrelia infections has not yet been confirmed in Brazil.

In Brazil, rural settlements are commonly characterized by inadequate sanitary care with people sharing the same environment with domestic and wild animals, in climate and environmental conditions favorable for the ticks. The present study aimed to survey humans, along with their dogs and horses, for anti-B. burgdorferi s.l. antibodies, to identify tick species present, and to determine risk factors associated with seropositivity in a rural settlement of Paraná State, southern Brazil.

\section{Materials and Methods}

\section{Ethical principles}

The present study was approved by the Ethics Committee in Animal Experimentation and Animal Welfare (protocol no. 82/2006) and by the Ethics Committee on Human Research (protocol no.124/2007) at the Universidade Estadual de Londrina.

\section{Study design}

The rural settlement of formerly landless people was characterized by inadequate infrastructure, low incomes, limited resources, and poor sanitary conditions, situated in Alvorada do Sul county

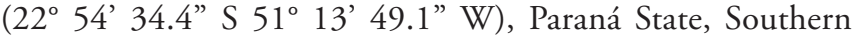
Brazil. The settlement was subdivided into 60 homesteads with approximately 12 hectares each. Humans, dogs, and horses shared the same environment, with continuous exposure to common ticks.

Samples were collected house-to-house between November 2006 and January 2007, at the end of spring and beginning of summer in the southern hemisphere. At the time of sampling, residents responded to an epidemiological questionnaire that included animal species, number, breed, age, and gender, and known presence or previous contact with ticks. The ages of dogs were stratified into groups of $<1$ year, $1-5$ years, and $>5$ years. The ages of horses were stratified into groups of $\leq 5$ years and $>5$ years. Resident age, gender, and known contact with ticks were also included in the questionnaire.

\section{Collection of ticks}

A total of 101 tick specimens were collected from dogs and horses during the study. Ticks from each host were removed using tweezers and placed in 70\% ethanol in labeled tubes. Ticks were later identified according to standard taxonomic keys (ARAGÃO \& FONSECA, 1961; GUIMARÃES et al., 2001; MARTINS et al., 2010; ONOFRIO et al., 2009).

\section{Sampling}

$\operatorname{Dog}(\mathrm{n}=83)$ and horse $(\mathrm{n}=18)$ blood samples (up to $10 \mathrm{~mL})$ were collected by veterinarians through jugular venipuncture, and human $(\mathrm{n}=87)$ blood samples were collected in the same visit by nurses through brachial venipuncture. All samples were collected in tubes without anti-coagulant, kept at room temperature $\left(25^{\circ} \mathrm{C}\right)$ until the clot visibly retracted, and then centrifuged at $1500 \mathrm{~g}$ for $5 \mathrm{~min}$. Serum was separated and kept at $-20^{\circ} \mathrm{C}$ until testing.

\section{Immunofluorescence antibody test (IFAT)}

Sera from dogs, horses, and humans were screened for anti- $B$. burgdorferi s.s. antibodies by indirect immunofluorescence antibody test (IFAT) using B. burgdorferi s.s. strain B31 for the antigen. The reaction was performed as previously described (COLLARES-PEREIRA et al., 2000), with fluorescein isothiocyanate-conjugated rabbit anti-dog IgG (Sigma-Aldrich, St. Louis, MO), rabbit anti-horse IgG (Sigma-Aldrich), and rabbit anti-human IgG (Sigma-Aldrich) used for testing of dog, horse, and human sera, respectively. Samples were considered positive when fluorescence was observed at dilutions of 1:64 or higher in dogs and horses or 1:128 or higher in humans. Antibody titers (endpoint titers) were defined as the reciprocal of the highest dilution of serum in which fluorescence was visualized. Positive and negative controls were provided by the Leptospirosis and Lyme Disease Group at the Universidade Nova de Lisboa, Portugal.

\section{Western blot (WB)}

Human sera that were positive by IFAT were subjected to western blot (WB) using a commercial kit (Anti-Borrelia EurolineRN-AT IgG, Euroimmun, Lübeck, Germany) that includes highly 
purified recombinant antigens of $B$. burgdorferi s.s. (Bb), B. afzelii $(\mathrm{Ba})$, and $B$. garinii $(\mathrm{Bg})$. This test was designed to detect the following antigens: recombinant VlsE from $\mathrm{Ba}, \mathrm{Bg}$, and $\mathrm{Bb}$; lipids from $\mathrm{Ba}$ and $\mathrm{Bb}$; 83 from $\mathrm{Ba}, \mathrm{p} 41$ from $\mathrm{Bg}$, p39 from $\mathrm{Bg}$, OspC from $\mathrm{Bg}$, and new recombinant antigens p58, p21, p20, p19, and p18. Procedures were performed according to the manufacturer's instructions and samples were considered positive when $\geq$ two reactive bands were present.

Dog sera that were positive by IFAT were subjected to WB using a commercial kit (recomBlot Borrelia canis IgG, Mikrogen, Germany), which was designed to detect anti-B. burgdorferi s.s., anti-B. garinii, anti-B. afzelii, and anti-B. bavariensis antibodies. The test contains highly purified recombinant $B$. burgdorferi antigens (OspA, OspC, p100, VlsE, p39, p18, and p41). All procedures were performed according to the manufacturer's instructions, and samples were considered positive when $\geq$ two reactive bands were present.

\section{Statistical analysis}

The Chi-square or Fisher's exact test was applied to determine the individual risk factors associated with antibody seropositivity to $B$. burgdorferi. Odds ratios (OR), 95\% confidence intervals, and $p$ values were calculated separately for each variable. Results were considered significant at $p<0.05$. Data were gathered and analyzed using freely available software (Epi Info version 3.5.3, Centers of Disease Control, Atlanta, GA, USA).

\section{Results}

Anti-B. burgdorferi antibodies were found in 4/87 (4.6\%; 95\% CI: 1.8-11.2) human residents by IFAT, with antibody titers ranging from 128 to 256 . Commercial WB revealed that $4 / 4(100 \%)$ positive human sera reacted to antigen $\mathrm{p} 41 \mathrm{Bg}$ and new recombinant antigens $\mathrm{p} 21, \mathrm{p} 20$, and p 19; $2 / 4$ (50\%) reacted to $\mathrm{p} 83 \mathrm{Ba}$ and $\mathrm{p} 39 \mathrm{Bg} ; 1 / 4(25 \%)$ reacted to $\mathrm{p} 39 \mathrm{Bg}$; and $1 / 4$ (25\%) reacted to the new recombinant antigen 18.

A total of 26/83 (31.3\%; 95\% CI: 22.3-41.9) dogs were determined seropositive for anti-B. burgdorferi antibodies by IFAT, with antibody titers ranging from 64 to 128 . In addition, 15/26 $(57.7 \%)$ dog sera were confirmed positive by commercial WB, with $12 / 15(80 \%)$ sera reacting to $\mathrm{p} 100,9 / 15(60 \%)$ to $\mathrm{p} 41,4 / 15$ (26.7\%) to $\mathrm{p} 39,3 / 15(20 \%)$ to OspC. Results of the 15 positive dogs on WB are summarized in Table 1 . No significant association was found between seropositivity to $B$. burgdorferi and dog age (Fisher's exact test: $p>0.05$ ), gender (Chi-square: $p=0.163$ ), or presence of ticks (Chi-square: $p=0.865$ ). The seroprevalence of $B$. burgdorferi in dogs and risk factors for infection are presented in Table 2.

An overall 7/18 (38.9\%; 95\% CI: 21.6-63.9) horses were determined seropositive for anti- $B$. burgdorferi antibodies by IFAT, with antibody titers ranging from 64 to 256 . No significant association was found between seropositivity to $B$. burgdorferi and horse age (Chi-square: $p=0.864)$, gender (Chi-square: $p=0.705)$, or presence of ticks (Chi-square: $p=0.4404)$.
Table 1. Results of immunofluorescence antibody testing (IFAT) and western blotting for anti-Borrelia sp. antibodies in dogs from a rural settlement, Paraná State, southern Brazil.

\begin{tabular}{ccc}
\hline Dogs & Antibody titer (IFAT) & Western Blot \\
\hline 12 & 64 & $\mathrm{p} 100, \mathrm{VlsE}, \mathrm{p} 41$ \\
21 & 128 & $\mathrm{p} 39$ \\
22 & 64 & $\mathrm{p} 41, \mathrm{OspC}$ \\
23 & 64 & $\mathrm{p} 41$ \\
24 & 64 & $\mathrm{p} 100, \mathrm{p} 41$ \\
26 & 128 & $\mathrm{p} 100$ \\
29 & 64 & $\mathrm{p} 100, \mathrm{p} 41$ \\
31 & 128 & $\mathrm{p} 100, \mathrm{p} 39, \mathrm{OspC}$ \\
45 & 64 & $\mathrm{p} 100, \mathrm{p} 41$ \\
46 & 64 & $\mathrm{p} 100, \mathrm{p} 41$ \\
53 & 64 & $\mathrm{p} 100, \mathrm{p} 41$ \\
60 & 128 & $\mathrm{p} 100, \mathrm{p} 39, \mathrm{O} \mathrm{pC}$ \\
66 & 128 & $\mathrm{p} 100$ \\
75 & 128 & $\mathrm{p} 100, \mathrm{p} 39$ \\
90 & 64 & $\mathrm{p} 100, \mathrm{p} 41$ \\
\hline
\end{tabular}

Table 2. Seroprevalence of anti-Borrelia burgdorferi antibodies and risk factors for Borrelia infection in dogs from a rural settlement, Paraná State, southern Brazil.

\begin{tabular}{lcccc}
\hline \multicolumn{1}{c}{ Variable } & $+\mathbf{N}(\%)$ & OR & 95\% CI & $\boldsymbol{p}$-value \\
\hline Presence of Ticks & & & & \\
$\quad$ Yes & $19 / 65(29.2 \%)$ & 2.06 & $0.53-7.96$ & 0.225 \\
$\quad$ No & $3 / 18(17.7 \%)$ & & & \\
Age (Years) & & & & \\
$\quad<1$ & $4 / 23(17.4 \%)$ & & & \\
$1-5$ & $15 / 48(31.3 \%)$ & 2.15 & $0.62-7.45$ & 0.217 \\
$>5$ & $3 / 12(25 \%)$ & 1.58 & $0.29-8.61$ & 0.453 \\
Gender & & & & \\
$\quad$ Male & $14 / 62(22.60)$ & 0.47 & $0.16-1.37$ & 0.163 \\
Female & $08 / 21(38.10)$ & & & \\
\hline
\end{tabular}

+ , Number of positive animals; $\mathrm{N}$, number of samples per variable; OR, odds ratio; 95\% CI, 95\% confidence interval.

Of the ticks collected, 67/101 (66.3\%; 95\% CI: 56.6-74.8) were from dogs and 34/101 (33.7\%; 95\% CI: 25.2-43.3) were from horses. Three tick species were identified on dogs: Rhipicephalus sanguineus ( $\mathrm{n}=45,67.1 \%)$, Amblyomma ovale ( $\mathrm{n}=21,31.4 \%$ ) and $A$. cajennense sensu lato $(\mathrm{n}=1,1.5 \%)$. From horses, all 34/34 (100\%) ticks were identified as A. cajennense sensu lato.

\section{Discussion}

Anti-B. burgdorferi antibodies were found in $31.3 \%$ of dogs, $38.9 \%$ of horses, and $4.6 \%$ of residents from the settlement. Antibody positivity to this organism has been previously described in subjects from rural areas of Brazil (GONÇALVES et al., 2013). However, to the author's knowledge, no survey or study to date has both assessed the anti-B. burgdorferi antibody prevalence in domestic animals and their corresponding owners and determined the risk factors associated with seropositivity. 
Human sera that were positive for anti-Borrelia antibodies by IFAT were confirmed positive by WB, as recommended by the U.S. Centers for Disease Control and Prevention (CDC, 2011). Interestingly, although the LD agent in Brazil may exhibit a different pattern of reactivity by WB when B. burgdorferi s.s. from the Northern Hemisphere is used (MANTOVANI et al., 2007; YOSHINARI et al., 2010), human sera from this study showed IgG reactivity by WB to $B$. garinii, $B$. afzelii, and $B$. burgdorferi antigens. The overlapping occurrence of these three Borrelia species has been only reported in the Palearctic region and associated to ticks belonging to the Ixodes ricinus complex (ESTRADA-PENÂ et al., 2011). Thus, the authors have not excluded the possibility that the anti-Borrelia IgG detected in the present study is a result of cross-reactivity with bacteria not belonging to the genus Borrelia or even with the BYS agent.

Antibody seropositivity to Borrelia spp. was found by WB in $18 \%$ of dogs in the present study, which is a higher prevalence than has been reported previously in tick endemic areas (JOPPERT et al., 2001; O'DWYER et al., 2004). Previous studies have shown cross-reactivity with antigens of other spirochetes, such as Leptospira antigens p41 and OspC (BRUCKBAUER et al., 1992; LESCHNIK et al., 2010), and it is important to note the possibility that dog sera in this study (untested for anti-Leptospira antibodies) may have tested positive by WB as result of cross-reactivity. However, since $80 \%$ dogs' sera also demonstrated antibodies against p100 by WB (Table 1), an antigen for which no cross-reactivity has been reported, the antibodies detected here are likely a result of Borrelia infection. In addition, the present study corroborates previous studies (O'DWYER et al., 2004) in which no association was established between seropositivity to Borrelia spp. and age, gender, or presence of ticks in dogs.

An overall $38.9 \%$ of horses were seropositive for anti-Borrelia spp. antibodies by IFAT. This seroprevalence was higher than previously reported by ELISA testing, with seroprevalences of $26.7 \%$ in urban cart horses in northern Brazil (GALO et al., 2009) and 28.4\% in farm horses in southeastern Brazil (MADUREIRA et al., 2007). Results suggest a much higher exposure of horses to ticks and Borrelia spp. at this rural settlement, which may differ from dog and human exposure since prevalence in dogs and owner were in agreement with previous studies.

Our research hypothesis is that tick-borne infections are common in Brazil, because of a favorable climate and high prevalence and wide distribution of ticks, and that these diseases are underestimated. Moreover, we hypothesize that two major groups of humans are at highest risk of Borrelia infection: immune-compromised and those that are highly exposed to ticks. Based on the results of the present study and a previous study by our group on Ehrlichia spp. in subjects highly exposed to ticks (VIEIRA et al., 2013a), the authors emphasize that physicians should consider tick-borne diseases in inhabitants from rural settlements in Brazil.

In conclusion, anti-Borrelia antibodies were found in dogs, horses and their owners in a rural settlement from southern Brazil. However, the lack of isolation, molecular characterization, absence of competent vectors and the low specificity of the commercial WB kit used herein may have impaired risk factor analysis.

\section{Acknowledgements}

This study was part of research toward a master's degree for Denise Nascimento at the Universidade Estadual de Londrina. Denise Nascimento was sponsored by a fellowship from the Coordenação de Aperfeiçoamento de Pessoal de Nível Superior (CAPES) at the time of the study. This study was supported by Fundação Araucária do Paraná (proc. 054/2007) and CNPq.

\section{References}

Alves AL, Madureira RC, Silva RA, Corrêa FN, Botteon RCCM. Freqüência de anticorpos contra Borrelia burgdorferi em cães na região metropolitana do Rio de Janeiro. Pesqui Vet Bras 2004; 24(4): 203-206. http://dx.doi.org/10.1590/S0100-736X2004000400006.

Aragão HB, Fonseca F. Notas de Ixodologia. VIII. Lista e chave para os representantes da fauna ixodológica brasileira. Mem Inst Oswaldo Cruz 1961; 59(2): 115-129. PMid:13861962. http://dx.doi.org/10.1590/ S0074-02761961000200001.

Barbieri AM, Venzal JM, Marcili A, Almeida AP, González EM, Labruna MB. Borrelia burgdorferi sensu lato infecting ticks of the Ixodes ricinus complex in Uruguay: first report for the Southern Hemisphere. Vector Borne Zoonotic Dis 2013; 13(3): 147-153. PMid:23402334. http://dx.doi. org/10.1089/vbz.2012.1102.

Bruckbauer HR, Preac-Mursic V, Fuchs R, Wilske B. Cross-reactive proteins of Borrelia burgdorferi. Eur J Clin Microbiol Infect Dis 1992; 11(3): 224-232. PMid:1597198. http://dx.doi.org/10.1007/BF02098084.

Carranza-Tamayo CO, Costa JNG, Bastos WM. Lyme disease in the state of Tocantins, Brazil: report of the first cases. Braz J Infect Dis 2012; 16(6): 586-589. PMid:23141972. http://dx.doi.org/10.1016/j.bjid.2012.07.013.

Centers for Disease Control and Prevention - CDC. Laboratory diagnostic testing for Borrelia burgdorferi infection [online]. Atlanta: CDC; 2011 [cited 2015 Oct 27]. Available from: http://www.cdc.gov/lyme/resources/ Halperin_2012_Chap4_JohnsonB.pdf

Collares-Pereira M, Santos SC, Vieira ML. Valor diagnóstico da técnica de imunofluorescência indireta com diferentes estirpes no rastreio da Borreliose de Lyme. Trab Soc Port Dermatol Venereol 2000; 58: 97-105.

Estrada-Peña A, Ortega C, Sánchez N, Desimone L, Sudre B, Suk JE, et al. Correlation of Borrelia burgdorferi sensu lato prevalence in questing Ixodes ricinus ticks with specific abiotic traits in the western palearctic. Appl Environ Microbiol 2011; 77(11): 3838-3845. PMid:21498767. http:// dx.doi.org/10.1128/AEM.00067-11.

Galo KR, Fonseca AH, Madureira RC, Barbosa JD No. Freqüência de anticorpos homólogos anti-Borrelia burgdorferi em eqüinos na mesorregião metropolitana de Belém, Estado do Pará. Pesqui Vet Bras 2009; 29(3): 229-232. http://dx.doi.org/10.1590/S0100-736X2009000300007.

Gonçalves DD, Benitez A, Lopes-Mori FM, Alves LA, Freire RL, Navarro IT, et al. Zoonoses in humans from small rural properties in Jataizinho, Parana, Brazil. Braz J Microbiol 2013; 44(1): 125-131. PMid:24159294. http://dx.doi.org/10.1590/S1517-83822013005000011.

Gonçalves DD, Carreira T, Nunes M, Benitez A, Lopes-Mori FM, Vidotto O, et al. First record of Borrelia burgdorferi B31 strain in Dermacentor nitens ticks in the northern region of Parana (Brazil). Braz J Microbiol 2014; 44(3): 883-887. PMid:24516456. http://dx.doi.org/10.1590/ S1517-83822013000300035. 
Guimarães JH, Tucci EC, Barros-Battesti DM. Ectoparasitos de importância veterinária. São Paulo: Editora Plêiade/FAPESP; 2001.

Joppert AM, Hagiwara MK, Yoshinari NH. Borrelia burgdorferi antibodies in dogs from Cotia County, São Paulo State, Brazil. Rev Inst Med Trop Sao Paulo 2001; 43(5): 251-255. PMid:11696846. http://dx.doi.org/10.1590/ S0036-46652001000500003.

Labarthe N, De Campos Pereira M, Barbarini O, McKee W, Coimbra CA, Hoskins J. Serologic prevalence of Dirofilaria immitis, Ehrlichia canis, and Borrelia burgdorferi infections in Brazil. Vet Ther 2003; 4(1): 67-75. PMid:12756637.

Leschnik MW, Kirtz G, Khanakah G, Duscher G, Leidinger E, Thalhammer JG, et al. Humoral immune response in dogs naturally infected with Borrelia burgdorferi sensu lato and in dogs after immunization with a Borrelia vaccine. Clin Vaccine Immunol 2010; 17(5): 828-835. PMid:20219882. http://dx.doi.org/10.1128/CVI.00427-09.

Madureira RC, Corrêa FN, Cunha NC, Guedes DS Jr, Fonseca AH. Ocorrência de anticorpos homólogos anti-Borrelia burgdorferi em eqüinos de propriedades dos municípios de Três Rios e Vassouras, estado do Rio de Janeiro. Rev Bras Ci Vet 2007; 14(1): 43-46.

Mantovani E, Costa IP, Gauditano G, Bonoldi VL, Higuchi ML, Yoshinari NH. Description of Lyme disease-like syndrome in Brazil. Is it a new tick borne disease or Lyme disease variation? Braz J Med Biol Res 2007; 40(4): 443-456. PMid:17401487. http://dx.doi.org/10.1590/ S0100-879X2007000400002.

Martins TF, Onofrio VC, Barros-Battesti DM, Labruna MB. Nymphs of the genus Amblyomma (Acari: Ixodidae) of Brazil: descriptions, redescriptions, and identification key. Ticks Tick Borne Dis 2010; 1(2): 75-99. PMid:21771514. http://dx.doi.org/10.1016/j.ttbdis.2010.03.002.

Nava S, Barbieri AM, Maya L, Colina R, Mangold AJ, Labruna MB, et al. Borrelia infection in Ixodes pararicinus ticks (Acari: Ixodidae) from northwestern Argentina. Acta Trop 2014; 139: 1-4. PMid:24979685. http://dx.doi.org/10.1016/j.actatropica.2014.06.010.

O’Dwyer LH, Soares SO, Massard CL, Souza JCP, Flausino W, Fonseca $\mathrm{AH}$. Soroprevalência de Borrelia burgdorferi latu sensu associada à presença de carrapatos em cáes de áreas rurais do Estado do Rio de Janeiro, Brasil. Cienc Rural 2004; 34(1): 201-205. http://dx.doi.org/10.1590/S010384782004000100031 .

Onofrio VC, Barros-Battesti DM, Labruna MB, Faccini JL. Diagnoses of and illustrated key to the species of Ixodes Latreille, 1795 (Acari: Ixodidae) from Brazil. Syst Parasitol 2009; 72(2): 143-157. PMid:19115087. http:// dx.doi.org/10.1007/s11230-008-9169-z.
Rosa NS No, Gauditano G, Yoshinari NH. Chronic lymphomonocytic meningoencephalitis, oligoarthritis and erythema nodosum: report of Baggio-Yoshinari syndrome of long and relapsing evolution. Rev Bras Reumatol 2014; 54(2): 148-151. PMid:24878862. http://dx.doi. org/10.1016/j.rbr.2014.03.010.

Spolidorio MG, Labruna MB, Machado RZ, Moraes-Filho J, Zago AM, Donatele DM, et al. Survey for tick-borne zoonoses in the state of Espirito Santo, southeastern Brazil. Am J Trop Med Hyg 2010; 83(1): 201-206. PMid:20595502. http://dx.doi.org/10.4269/ajtmh.2010.09-0595.

Stanek G, Reiter M. The expanding Lyme Borrelia complex — clinical significance of genomic species? Clin Microbiol Infect 2011; 17(4): 487-493. PMid:21414082. http://dx.doi.org/10.1111/j.1469-0691.2011.03492.x.

Stanek G, Wormser GP, Gray J, Strle F. Lyme borreliosis. Lancet 2012; 379(9814): 461-473. PMid:21903253. http://dx.doi.org/10.1016/ S0140-6736(11)60103-7.

Vieira RF, Vieira TS, Nascimento DA, Martins TF, Krawczak FS, Labruna MB, et al. Serological survey of Ehrlichia species in dogs, horses and humans: zoonotic scenery in a rural settlement from southern Brazil. Rev Inst Med Trop Sao Paulo 2013a; 55(5): 335-340. PMid:24037288. http://dx.doi.org/10.1590/S0036-46652013000500007.

Vieira TS, Vieira RF, Nascimento DA, Tamekuni K, Toledo RS, Chandrashekar R, et al. Serosurvey of tick-borne pathogens in dogs from urban and rural areas from Parana State, Brazil. Rev Bras Parasitol Vet 2013b; 22(1): 104-109. PMid:24252955. http://dx.doi.org/10.1590/ S1984-29612013000100019.

Yoshinari N, Spolidorio M, Bonoldi VL, Sotto M. Lyme disease like syndrome associated lymphocytoma: first case report in Brazil. Clinics 2007; 62(4): 525-526. PMid:17823716. http://dx.doi.org/10.1590/ S1807-59322007000400020.

Yoshinari NH, Abrão MG, Bonoldi VL, Soares CO, Madruga CR, Scofield A, et al. Coexistence of antibodies to tick-borne agents of babesiosis and Lyme borreliosis in patients from Cotia county, State of São Paulo, Brazil. Mem Inst Oswaldo Cruz 2003; 98(3):311-318. PMid:12886408. http:// dx.doi.org/10.1590/S0074-02762003000300004.

Yoshinari NH, Mantovani E, Bonoldi VL, Marangoni RG, Gauditano G. Doença de Lyme-símile brasileira ou síndrome Baggio-Yoshinari: zoonose exótica e emergente transmitida por carrapatos. Rev Assoc Med Bras 2010; 56(3): 363-369. PMid:20676548. http://dx.doi.org/10.1590/ S0104-42302010000300025. 